\title{
Service Quality Towards Bank Customer Loyalty (Empirical Study at BNI USU Medan)
}

\author{
Dedy Ansari Harahap, Ratih Hurriyati, Disman, Vanessa Gaffar and Dita Amanah
}

\begin{abstract}
This study aims to analyze the influence of service quality on customer loyalty at PT. BNI (Persero), Tbk USU Medan. This study used a quantitative approach with an explanatory type of research. The sample were 120 respondents and processed statistically using simple linear regression method. The results show that service quality positively has a significant effect on customer loyalty. These findings indicate that good service quality will encourage the interest of customers to conduct transactions continuously and repeatedly in the present and future in a bank.
\end{abstract} BNI.

Index Terms - Service quality, customer loyalty, banking,

\section{INTRODUCTION}

The level of competition in the business world is increasingly fierce, making every mar keter required to be more creative and not just improve product quality alone. The difference between one product and similar products from competitors is getting smaller, where service quality is the main key in competing to meet the needs of consumers. It is increasingly recognized that service quality is a vital aspect of staying in business and winning competition. Whether or not a banking company is resilient is determined by the bank's ability to provide satisfying services to customers. In today's global market, competitive advantage lies in providing high quality services to customers in every organization. The financial services industry is now facing a rapidly changing market situation with new technology, economic uncertainty, fierce competition and demands from customers who want more services.

Banking is currently experiencing very rapid development, giving rise to a competitive and tight banking business. This cannot be denied anymore, where each bank is required to implement various methods in attracting the interest of the public. The banking industry is aware that increasingly intense competition to attract customers requires quality marketing and excellent service. According

Dedy Ansari Harahap is a Lecturer at Faculty of Economics and Business, Universitas Islam Bandung, J1. Tamansari No.1, Bandung, West Java 40116, Indonesia (e-mail: deanhar@yahoo.com).

Ratih Hurriyati is a Senior Lecturer at Faculty of Economic Education and Business, Universitas Pendidikan Indonesia, Jl. Dr. Setiabudi No.229, Isola, Bandung, West Java 40154, Indonesia (e-mail: ratih@upi.edu).

Disman is a Senior Lecturer at Faculty of Economic Education and Business, Universitas Pendidikan Indonesia, Jl. Dr. Setiabudi No.229, Isola, Bandung, West Java 40154, Indonesia (e-mail: disman@upi.edu).

Vanessa Gaffar is a Senior Lecturer at Faculty of Economic Education and Business, Universitas Pendidikan Indonesia, J1. Dr. Setiabudi No.229, Isola, Bandung, West Java 40154, Indonesia (e-mail: vanessa@upi.edu).

Dita Amanah is a Senior Lecturer at Faculty of Economic, Universitas Negeri Medan, Jalan Willem Iskandar Pasar V Medan Estate, Medan, 20221, Indonesia (e-mail: ditamnh@yahoo.com). to [1], service quality is defined as the level of quality where quality control is carried out to achieve good quality in accordance with consumer desires.

Banking is demanded to always improve the quality of its services by always paying attention to the needs and expectations of customers. Services must be designed so that customers always feel satisfied and ultimately have a high loyalty to the bank or bank products, so that banks can achieve high profitability and continue to grow and develop in accordance with the demands of competition and become a formidable market leader. Banks must be able to maintain good performance and improve what is still lacking from the assessment of customers who use their services in the future [2].

Loyalty certainly will not be achieved if it is not equipped with the quality of what is being carried out by the company. In this connection, the quality expressed in this study is the quality of service. The service quality dimension proposed by [3] consists of five (5) namely; tangibles, reliability, responsiveness, assurance and empathy. These five dimensions are known as SERVQUAL.

BNI USU Medan is the main branch office located in the North Sumater University (USU) area which is one of the largest campuses in North Sumatra, located in Medan. Customers are not only the public, but also USU students, staff and lecturers who conduct transactions at this bank. This bank is very strategically located that can help everyone who does business around the bank. The bank also holds USU lecturer and staff salary accounts, USU entry registration payments and student tuition payments. This bank has undergone many updates on physical buildings in 2017-2018, so it is known as the bank that has the best service, fast, clean and comfortable [4].

To assess the quality level of bank services, five dimensions of service quality are used, namely: tangibles, reliability, responsiveness, assurance and empathy. Of the five dimensions obtained by the customer assessment of BNI so that it can be seen its effect on loyalty. From the above phenomenon, the writer is interested in examining the problem with the title "Service Quality Towards Bank Customer Loyalty (Empirical Study at BNI USU Medan)".

\section{THEORETICAL FRAMEWORK AND FORMULATION OF HYPOTHESES}

\section{A. Customer Loyalty}

Loyalty is something that causes consumers to choose a brand, service, shop, product and certain activities. Loyalty is more to a feature owned by consumers and not just to something related to a brand [5]. Loyalty is a way for consumers to express their satisfaction with the 
performance of the goods or services they receive [6].

Customer loyalty is a customer who not only repurchases goods and services, but also has a commitment and a positive attitude towards the company, for example by recommending others to buy [7]. Customer loyalty is often related to the customer's willingness to repeatedly buy goods or services accompanied by psychological ties and favorable attitudes towards goods / services or companies [8],[9]. Customer loyalty is the desire and willingness of customers to always do personal or business transactions at a bank repeatedly and consistently despite changes in the future [10].

Research on consumer loyalty has focused primarily on product or brand loyalty, whereas loyalty to services has rarely been published [11]. Always, a very significant relationship between product satisfaction and loyalty is reported. Referring to customer loyalty, service quality is the key word [12]. There are several reasons why research on product loyalty cannot be generalized to service loyalty [11],[13].

Service loyalty is more directed towards the formation of interpersonal relationships that are different from product loyalty [14], a form of interaction between individuals which is an important element in service marketing [15],[16],[17],[18]. Furthermore, the perceived risk of consumers is greater in service businesses as consumer loyalty is a barrier to consumer switching behavior [19], [20],[21]. Loyalty is more commonly demonstrated by service companies than product-producing companies [22] In the service context, intangible attributes such as trustworthy factors and beliefs play an important role in shaping loyalty [23].

\section{B. Service Quality}

Service quality is the attitude and assessment of consumers globally related to services and the results of the comparison of perceptions and expectations with services actually received by consumers [3], [24], [25]. In general, consumer expectations are increasing and they are increasingly critical of the quality of the services they receive.

Quality of service has received much attention from researchers and practitioners in the past two decades. Practitioners believe that service quality can improve company performance [26],[27],[28],[29],[30],[31].

[32], assesses service quality as a measure of how well service is delivered in accordance with customer expectations, while according to [33], service quality refers to customer perceptions about the difference between expected and actual services. The quality of bank services is a form of assessment of the level of service provided by banks to customers to meet the needs and desires of customers in accordance with their expectations [10].

The service quality model has given much attention after the revolutionary work of [3]. In their research revealed 10 dimensions of service quality measurement and proposed a service quality gap model. In 1988, they reduced 10 service quality measurement dimensions to 5 dimensions. They made a questionnaire of 22 items and suggested it as a SERVQUAL model. [34],[35], further stated that the SERVQUAL model has diagnostic characteristics and has several practical implications.

This SERVQUAL model has been used by many academic researchers and also the service industry [36],[37],[38],[39],[40],[41],[42],[43]. The five dimensions of service quality are as follows:

Tangible is a tangible element of a service and includes aspects such as physical appearance, tools and equipment, personnel and communication materials [44]. [45], describe tangible in SERVQUAL as a "solid" dimension used to assess service quality. Because services are real, customer perceptions about service quality are tangible comparisons related to services provided. This is the appearance of physical facilities, equipment, personnel and communication materials [46].

Assurance is employee knowledge about politeness and the ability of companies and employees to inspire customer trust [46]. The guarantee dimension addresses the security and privacy felt by customers. In the service quality literature, trust is considered as' trust in service itself sendiri [3],[24]. The assurance dimension in SERVQUAL refers to the knowledge and courtesy of employees and their ability to inspire trust and confidence [24].

Reliability is the company's ability to perform the promised service reliably and accurately. For example the company gives promises about delivery, service provision, problem resolution and pricing. Customers want to do business with companies that keep their promises, especially their promises about service results and core service attributes. All companies must be aware of customer expectations for reliability [47]. This refers to the accuracy of the requested service delivery in an accurate and in line with advertised attributes [48],[3],[49].

Responsiveness is the desire of the company to help customers and provide fast service. This dimension emphasizes attention and timeliness in handling customer requests, questions, complaints and problems. Responsiveness is communicated to customers with the length of time they have to wait for help, answers to questions or attention to problems [47]. Responsiveness refers to providing services and handling problems in a timely and convenient way [48]. The responsive dimension can be understood as from traditional SERVQUAL [50]. It measures the ability and willingness of companies to provide fast service when customers have questions / problems [50].

Empathy is a company giving individual attention to show customers that the company is doing its best to satisfy their needs. Empathy is the added value of customer trust and at the same time can increase loyalty [47].

In the banking industry, service quality plays an important role in increasing customer satisfaction. [51], shows that a strong relationship between a bank and a customer builds customer loyalty which gives the bank a competitive advantage. Likewise, [52] describes the longterm relationship between banks and customer satisfaction. [53], establishes various dimensions of service quality in banking, while [54], empirically finds that customers consider reliability and security as the most important quality of bank services, followed by responsiveness, communication and competence. On the contrary, cleanliness, comfort and aesthetics prove to be the least 
important.

\section{Hypothesis}

Based on the description that has been explained in the introduction and literature review, the formulation of the hypothesis in this study is:

H1: The better the quality of service received by the customer, the more loyal the customer is to PT. BNI (Persero) Tbk, USU Medan.

\section{RESEARCH METHODS}

This research was conducted at PT. BNI (Persero) Tbk, USU Medan. Primary and population data for this study were obtained through a questionnaire survey of a sample of customers who transacted at BNI USU Medan Branch. The collection of questions explores service quality which consists of Tangible, Assurance, Reliability, Responsiveness and Empathy dimensions related to customer loyalty. Each respondent answers the selected questionnaire by giving a determined alternative ranking. Questions are measured on a five-point Likert scale, with the following conditions: 1 strongly disagree, 2 disagree, 3 doubt, 4 agree and 5 strongly agree

The population in this study were all customers who had transacted at USU Bank BNI Medan. To get the right sampling frame, non probability sampling was then chosen as a sampling technique that was more appropriate for the purpose of this study. Respondents were chosen randomly from customers who came to the bank. Of the 130 questionnaires distributed, only 120 were suitable for analysis. Data collection techniques by distributing questionnaires related to service quality on customer loyalty.

The quantitative approach is used with the type of explanatory research as a data analysis technique. Simple linear regression analysis is performed to test the relationship between the independent variable (service quality) and the dependent variable (customer loyalty) tested as in hypotheses 1-5.

\section{RESULTS AND DISCUSSION}

A. Results

1. Validity and Reliability Test

Table 1. Validity and Reliability Test Results

\begin{tabular}{|c|c|c|c|c|c|c|c|}
\hline Variable & Statement & $\mathbf{r}$ & $\mathbf{r}_{\text {table }}$ & Status & $\begin{array}{c}\text { Cronbach } \\
\text { Alpha }\end{array}$ & $\mathbf{r}$ table & Status \\
\hline $\begin{array}{l}\text { Service } \\
\text { Quality } \\
(\mathrm{X})\end{array}$ & $\begin{array}{l}X_{1} \\
X_{2} \\
X_{3} \\
X_{4} \\
X_{5} \\
X_{6} \\
X_{7} \\
X_{8} \\
X_{9} \\
X_{10} \\
X_{11} \\
X_{12} \\
X_{13} \\
X_{14} \\
X_{15} \\
X_{16} \\
X_{17} \\
X_{18} \\
X_{19} \\
X_{20} \\
X_{21} \\
X_{22} \\
\end{array}$ & $\begin{array}{l}.516 \\
.750 \\
.475 \\
.604 \\
.566 \\
.372 \\
.766 \\
.620 \\
.658 \\
.706 \\
.512 \\
.696 \\
.396 \\
.775 \\
.792 \\
.642 \\
.712 \\
.781 \\
.609 \\
.751 \\
.538 \\
.804 \\
\end{array}$ & $\begin{array}{l}.361 \\
.361 \\
.361 \\
.361 \\
.361 \\
.361 \\
.361 \\
361 \\
.361 \\
.361 \\
.361 \\
.361 \\
.361 \\
.361 \\
.361 \\
.361 \\
.361 \\
.361 \\
.361 \\
.361 \\
.361 \\
.361 \\
\end{array}$ & $\begin{array}{l}\text { Valid } \\
\text { Valid } \\
\text { Valid } \\
\text { Valid } \\
\text { Valid } \\
\text { Valid } \\
\text { Valid } \\
\text { Valid } \\
\text { Valid } \\
\text { Valid } \\
\text { Valid } \\
\text { Valid } \\
\text { Valid } \\
\text { Valid } \\
\text { Valid } \\
\text { Valid } \\
\text { Valid } \\
\text { Valid } \\
\text { Valid } \\
\text { Valid } \\
\text { Valid } \\
\text { Valid } \\
\end{array}$ & .941 & .361 & Reliable \\
\hline $\begin{array}{l}\text { Customer } \\
\text { Loyalty (Y) }\end{array}$ & $\begin{array}{l}\mathrm{Y}_{1} \\
\mathrm{Y}_{2} \\
\mathrm{Y}_{3} \\
\mathrm{Y}_{4} \\
\mathrm{Y}_{5} \\
\mathrm{Y}_{6} \\
\mathrm{Y}_{7} \\
\mathrm{Y}_{8} \\
\mathrm{Y}_{9} \\
\mathrm{Y}_{10}\end{array}$ & $\begin{array}{l}.572 \\
.466 \\
.517 \\
.546 \\
.644 \\
-.449 \\
.484 \\
.220 \\
.060 \\
.424 \\
\end{array}$ & $\begin{array}{l}.361 \\
.361 \\
.361 \\
.361 \\
.361 \\
.361 \\
.361 \\
.361 \\
.361 \\
.361\end{array}$ & $\begin{array}{c}\text { Valid } \\
\text { Valid } \\
\text { Valid } \\
\text { Valid } \\
\text { Valid } \\
\text { Invalid } \\
\text { Valid } \\
\text { Invalid } \\
\text { Invalid } \\
\text { Valid } \\
\end{array}$ & .659 & .361 & Reliable \\
\hline
\end{tabular}


Table 1 shows 22 (twenty two) statement items on the service quality variable declared valid where the value of $r>$ r-table at a significance of 0.05 with the value of r-table is 0.361 . For customer loyalty variables, 7 items are declared valid while 3 are invalid, where the value of $r>$ r-table at a significant level of 0.05 with the value of $r$ table is 0.361 . The results of the reliability calculation using the Cronbach alpha test on service quality are 0.941 and the customer loyalty variable is 0.659 . This value is greater than the $r$ table value at the significant level of 0.05 which is equal to 0.361 . So it can be concluded that the instruments used in this research questionnaire were reliable.

\section{Simple Regression Analysis}

The simple regression model equation with the dependent variable $(\mathrm{Y})$ is customer loyalty and the independent variable $(\mathrm{X})$ namely service quality is:

$$
\mathrm{Y}=\mathbf{0 . 1 1 1}+\mathbf{0 . 1 0 7 X}+\mathrm{e}
$$

Table 2. Simple Linear Regression

\begin{tabular}{lc}
\hline Model & $\begin{array}{c}\text { Unstandarized } \\
\text { Coefficients }\end{array}$ \\
\cline { 2 - 2 } & $\boldsymbol{B}$ \\
\hline (Constant) & .111 \\
Service Quality & .107 \\
\hline
\end{tabular}

Source: Data Processing

Table 2 shows the regression equation $\mathrm{Y}=0.111+0.107$ $\mathrm{X}+\mathrm{e}$ illustrates that if service quality changes by 1 unit and the other is constant, then customer loyalty changes by 0.107 . A constant of 0.111 provides an understanding that if the quality of service does not change or is equal to zero

\section{B. Discussion}

The results of the study stated that there was a positive and significant influence on service quality on the loyalty of USU BNI customers. This is indicated by the value of the service quality regression coefficient with $9.277>1.658$ at a significance level of $0.000<0.05$.

This result is supported by [55],[56], who stated that there is a strong relationship between service quality and customer loyalty. Quality of service can bring customer intention to re-use services at a bank, so that it will have an impact on customer loyalty.

In line with [35], which argues that service quality is superior quality to customers and brings customer loyalty. Good service quality will convince customers to repeat their requests for services provided by the company. This shows the customer towards the service provider. Quality services that meet customer expectations will get customer loyalty. This customer intention tends to benefit companies that provide more services than other companies that offer average services [57].

$\mathrm{R}^{2}$ value of 0.422 which means that service quality has an influence on customer loyalty of $42.20 \%$, while the remaining $57.80 \%$ is explained by other factors outside of this research variable. then customer loyalty is 0.111 .

3. The t Test

Table 3. $t$ Test

\begin{tabular}{lcc}
\hline \multirow{2}{*}{ Model } & \multicolumn{2}{c}{ t Test } \\
\cline { 2 - 3 } & \multicolumn{1}{c}{$\mathbf{t}$} & t table \\
\hline (Constant) & 2.474 & 1.658 \\
Service Quality & 9.276 & 1.658 \\
\hline
\end{tabular}

Source: Data Processing

The results of the partial test analysis (t-test) on the variable service quality $(\mathrm{X})$ obtained a $\mathrm{t}$ is 9.277 while the $\mathrm{t}-$ table is 1.658. The value of $\mathrm{t}>\mathrm{t}$-table, then Hol is rejected and Hal is accepted. This means that the hypothesis is accepted, that service quality significantly influences customer loyalty.

\section{Coefficient of Determination}

Table 4. Coefficient of Determination $\left(R^{2}\right)$

\begin{tabular}{cccc} 
Model & R & $\boldsymbol{R}$ Square & Adjusted $\boldsymbol{R}$ Square \\
\hline 1 & $.649^{\mathrm{a}}$ & .422 & .417 \\
\hline
\end{tabular}

Source: Data Processing

Table 3 shows that the value of $\mathrm{R}$ is 0.649 meaning that service quality has a strong relationship with customer loyalty. The value of $\mathrm{R}$ square $\left(\mathrm{R}^{2}\right)$ is 0.422 or $42.20 \%$ meaning that the influence of service quality on customer loyalty is $42.20 \%$ and the remaining $57.80 \%$ is influenced by other variables outside this study.

\section{CONCLUSIONS, IMPLICATIONS, SUGGESTIONS AND LIMITATIONS OF RESEARCH}

\section{A. Conclusions}

Based on the results of a simple regression analysis with partial hypothesis test calculations ( $t$-test), it is stated that service quality has a positive and significant effect on customer loyalty with a value of $\mathrm{t}>\mathrm{t}$-table, this states that $\mathrm{HO}$ is rejected and $\mathrm{Ha}$ is accepted, thus it can be concluded that service quality positively has a significant effect on customer loyalty.

\section{B. Implications}

The banking industry must always pay attention to customers in meeting their needs and desires by providing excellent service so that customers become satisfied and so be loyal to the bank. Banks can find out how far the quality of services that have been provided to customers, so they can identify factors that need to be maintained or improved in relation to bank services to customers in the future.

The quality of service attributes involved may be inadequate so other attributes need to be included. The object of research is only at BNI USU and needs to be extended to other banks so that more accurate results are expected. The number of samples is considered not representative and needs to be expanded because it is only 
limited to USU BNI customers.

\section{Research Limitations and Suggestions}

This study simply focuses on service quality variables as a factor that affects customer loyalty so that it is only able to explain at $42.20 \%$. The next researcher is expected to be able to add other variables such as image, satisfaction, WOM and marketing mix that can affect customer loyalty, need to expand the sample not only in one bank but from various banks so that the expected results can be generalized, and the number of samples needs to be expanded to provide more accurate results. Thusthat can give a good contribution to further research on customer loyalty in banking.

\section{REFERENCES}

[1] C. Lovelock, P. Patterson, and J. Wirtz, Services Marketing, 6th Editio. Australia: Pearson Australia, 2014.

[2] D. A. Harahap and D. Amanah, "Studi Kepuasan Nasabah PT. Bank Negara Indonesia (Persero), Tbk Kantor Cabang Pembantu UPI Bandung," J. Manaj. dan Bisnis Performa, vol. 16, no. 1, pp. $29-38,2019$.

[3] A. Parasuraman, V. A. Zeithaml, and L. L. Berry, "A Conceptual Model of Service Quality and Its Implications for Future Research," J. Mark., vol. 49, no. 4, pp. 41-50, 1985.

[4] IDLokasi, "Bank BNI Cabang USU Medan, Bank BNI Di Jalan Dr Mansyur," Medan, 2018.

[5] M. Uncles, "From Marketing Knowledge to Marketing Principles," Mark. Theory, vol. 2, no. 4, pp. 345-353, 2002.

[6] E. Delgado-Ballester and J. Luis Munuera-Alemán, "Brand trust in the context of consumer loyalty," Eur. J. Mark., vol. 35, no. 11/12, pp. 1238-1258, 2001.

[7] D. D. Gremler and S. W. Brown, "The loyalty ripple effect : Appreciating the full value of customers," Int. J. Serv. Ind. Manag., vol. 10, no. 3, pp. 271-291, 1999.

[8] Z. Deng, Y. Lu, K. Kee, and J. Zhang, "Understanding customer satisfaction and loyalty: An empirical study of mobile instant messages in China," Int. J. Inf. Manage., vol. 30, no. 4, pp. 289300,2010

[9] A. Wong and A. Sohal, "Service quality and customer loyalty perspectives on two levels of retail relationships," J. Serv. Mark., vol. 17 , no. 5, pp. 495-513, 2003.

[10] D. A. Harahap and D. Amanah, "Kajian Kualitas Pelayanan dan Loyalitas Nasabah Perbankan di Indonesia," J. Bisnis dan Ekon., vol. 26 , no. 1, pp. 30-43, 2019.

[11] D. D. Gremler and S. W. Brown, "Service loyalty: Its Nature, Importance, and Implications," Adv. Serv. Qual. A Glob. Perspect., no. January 1996, pp. 171-180, 1996.

[12] A. S. Dick and K. Basu, "Customer Loyalty: Toward an Integrated Conceptual Framework," J. Acad. Mark. Sci., vol. 22, no. 2, pp. 99-113, 1994.

[13] S. M. Keaveney, "Customer Switching Behavior in Service Industries: An Exploratory Study," J. Mark., vol. 59, no. 2, pp. 71-82, 1995.

[14] G. Macintosh and L. S. Lockshin, "Retail relationships and store loyalty: A multi-level perspective," Int. J. Res. Mark., vol. 14, no. 5, pp. 487-497, 1997.

[15] J. A. Czepiel and R. Gilmore, "'Exploring the Concept of Loyalty in Services,' in The Services Marketing Challenge: Integrating for Competitive Advantage, J. A. Czepiel, C. A. Congram, and J. Shanahan," in IL: AMA, Chicago, 1987, pp. 91-94.

[16] L. A. Crosby, K. R. Evans, and D. Cowles, "Relationship Quality in Services Selling: An Interpersonal Influence Perspective," $J$. Mark., vol. 54, no. 3, pp. 68-81, 1990.

[17] J. A. Czepiel, "Service Encounters and Service Relationships: Implications for Research,” J. Bus. Res., vol. 20, no. 1, pp. 13-21, 1990.

[18] C. F. Surprenant and M. R. Solomon, "Predictability and Personalization in the Service Encounter," J. Mark., vol. 51, no. April, pp. 86-96, 1987.

[19] J. P. Guiltinan, "A classification of switching costs with implications for relationship marketing," in AMA Winter Educators' Conference: Marketing theory and practice, 1989, pp.
216-220.

[20] P. Klemperer, "The Competitiveness of Markets With Switching Costs," Rand J. Econ., vol. 18, no. 1, pp. 138-150, 1987.

[21] V. A. Zeithaml, "How Consumer Evaluation Processes Differ Between Goods and Service, In Marketing of Services," Am. Mark. Assoc., pp. 186-190, 1981.

[22] M. Snyder and S. Gangestad, "On the Nature of Self-Monitoring: Matters of Assessment, Matters of Validity.," J. Pers. Soc. Psychol., vol. 51, no. 1, pp. 125-139, 1986.

[23] A. S. Dick and K. Basu, "Customer Loyalty: Toward an Integrated Conceptual Framework," J. Acad. Mark. Sci., vol. 22, no. 2, pp. 99-113, 1994.

[24] A. Parasuraman, V. A. Zeithaml, and L. L. Berry, "SERQUAL: A Multiple-Item Scale for Measuring Consumer Perceptions of Service Quality,"J. Retail., vol. 64, no. 1, pp. 12-40, 1988.

[25] C. Gronroos, "Service Management : A Management Focus for Service Competition," Int. J. Serv. Ind. Manag., vol. 1, no. 1, pp. 6-14, 1990.

[26] M. Al-Hawari and T. Ward, "The effect of automated service quality on Australian banks' financial performance and the mediating role of customer satisfaction," Mark. Intell. Plan., vol. 24, no. 2, pp. 127-147, 2006.

[27] S. Black, S. Briggs, and W. Keogh, "Service quality performance measurement in public / private sectors," Manag. Audit. J., vol. 16, no. 7, pp. 400-405, 2001.

[28] A. Caruana, A. H. Money, and P. R. Berthon, "Service quality and satisfaction - the moderating role of value," Eur. J. Mark., vol. 34 , no. $11 / 12$, pp. 1338-1353, 2000.

[29] T. K. Cheruiyot and L. C. Maru, "Service quality and relative performance of public universities in East Africa," TQM J., vol. 25 , no. 5, pp. 533-546, 2013.

[30] P. Haynes and G. Fryer, "Human resources, service quality and performance : a case study," Int. J. Contemp. Hosp. Manag., vol. 12, no. 4, pp. 240-248, 2000.

[31] D. K. Yoo and J. A. Park, "Perceived service quality: Analyzing relationships among employees, customers, and financial performance," Int. J. Qual. Reliab. Manag., vol. 24, no. 9, pp. 908-926, 2007.

[32] R. C. Lewis and B. H. Booms, The marketing aspects of service quality, in Berry, L.L., Shostack, G. and Upah, G. (Eds), Emerging Perspectives in Service Marketing. Chicago, 1983. C. Gronroos, "Strategic Management and Marketing in the Service Sector," Helsingfors, Report No. 83-104, 1983.

[34] A. Parasuraman, L. L. Berry, and V. A. Zeithaml, "Refinement and Reassessment of the SERVQUAL scale," J. Retail., vol. 67, no. 4, pp. 420-450, 1991.

[35] V. A. Zeithaml, L. L. Berry, and A. Parasuraman, "Behavioral Consequences of Service Quality," J. Mark., vol. 60, no. 2, pp. 31-46, 1996.

[36] H. M. Awan, K. S. Bukhari, and A. Iqbal, "Service quality and customer satisfaction in the banking sector: A comparative study of conventional and Islamic banks in Pakistan," J. Islam. Mark., vol. 2, no. 3, pp. 203-224, 2011.

[37] C. C. Cui, B. R. Lewis, and W. Park, "Service quality measurement in the banking sector in South Korea," Int. J. Bank Mark., vol. 21, no. 4, pp. 191-201, 2003.

[38] D. A. Harahap, "Hubungan Kualitas dan Loyalitas Nasabah Jasa Perbankan PT. Bank Rakyat Indonesia (Persero), Tbk Kota Medan,” Program Pascasarjana Syiah Kuala Banda Aceh, 2006.

[39] K. S. Woo and S. S. K. Lam, "Measuring service quality : A testretest reliability investigation of SERVQUAL," Mark. Res. Soc. J. Mark. Res. Soc., vol. 39, no. 2, pp. 381-396, 1997.

[40] M. Ali and S. A. Raza, "Service quality perception and customer satisfaction in Islamic banks of Pakistan: the modified SERVQUAL model," Total Qual. Manag. Bus. Excell., vol. 28, no. 5-6, pp. 1-19, 2015.

[41] G. S. Sureshchandar, C. Rajendran, and R. N. Anantharaman, "Customer perceptions of service quality in the banking sector of a developing economy: A critical analysis," Int. J. Bank Mark., vol. 21, no. 5, pp. 233-242, 2003.

[42] Y. Wang, H. Lo, and Y. V. Hui, "The antecedents of service quality and product quality and their influences on bank reputation: evidence from the banking industry in China," Manag. Serv. Qual. An Int. J., vol. 13, no. 1, pp. 72-83, 2003.

[43] U. Yavas, Z. Bilgin, and D. Shemwell, "Service quality in the banking sector in an emerging economy: a consumer survey," Int. J. Bank Mark., vol. 15, no. 6, pp. 217-223, 1997.

[44] J. Santos, "From intangibility to tangibility on service quality perceptions: a comparison study between consumers and service providers in four service industries," Manag. Serv. Qual. An Int. 
J., vol. 12, no. 5, pp. 292-302, 2002.

[45] A. Parasuraman, V. A. Zeithaml, and L. L. Berry, "SERQUAL: A Multiple-Item Scale for Measuring Consumer Perceptions of

Service Quality,"J. Retail., vol. 64, no. 1, pp. 12-40, 1988.

[46] U. Essay, "The Five Dimensions Of Service Quality Measured Marketing Essay,” Inggris, 2015.

[47] U. Essay, "The Five Dimensions Of Service Quality Measured Marketing Essay,” Inggris, 2015.

[48] M. Jun and S. Cai, "The key determinants of Internet banking service quality : a content analysis," Int. J. Bank Mark., vol. 19, no. 7, pp. 275-291, 2001.

[49] Z. Yang and X. Fang, "Online service quality dimensions and their relationships with satisfaction: A content analysis of customer reviews of securities brokerage services," Int. J. Serv. Ind. Manag., vol. 15, no. 3, pp. 302-326, 2004.

[50] V. A. Zeithaml, A. Parasuraman, and A. Malhotra, "Service Quality Delivery Through Web Sites: A Critical Review of Extant Knowledge," J. Acad. Mark. Sci., vol. 30, no. 4, pp. 362375, 2002.

[51] L. L. Berry and T. W. Thompson, "Relationship banking: the art of turning customers into clients," J. Retail Bank., vol. June, pp. 64-73, 1982.

[52] K. R. Teas, "Expectations as a comparison standard in measuring service quality : An assess ...," J. Mark., vol. 58, no. 1, pp. 132139, 1994.

[53] R. Johnston, "The Determinants of Service Quality: Satisfiers and Dissatisfiers,” Int. J. Serv. Ind. Manag., vol. 6, no. 5, pp. 53-71, 1995.

[54] R. Johnston, "Identifying the critical determinants of service quality in retail banking: Importance and effect," Int. J. Bank Mark., vol. 15, no. 4, pp. 111-116, 1997.

[55] Y. F. Kuo, C. M. Wu, and W. J. Deng, "The relationships among service quality, perceived value, customer satisfaction, and postpurchase intention in mobile value-added services," Comput. Human Behav., vol. 25, no. 4, pp. 887-896, 2009.

[56] I. G. Saura, D. S. Frances, G. B. Contr1, and M. F. Blasco, "Logistics service quality: a new way to loyalty," Ind. Manag. Data Syst., vol. 108, no. 5, pp. 650-668, 2008.

[57] V. Kaura, C. S. D. Prasad, and S. Sharma, "Service quality, service convenience, price and fairness, customer loyalty, and the mediating role of customer satisfaction," Int. J. Bank Mark., vol. 33, no. 4, pp. 1-32, 2015.

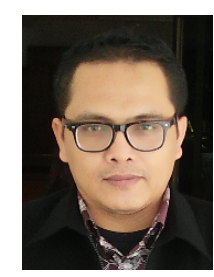

Dedy Ansari Harahap earned his undergraduate degree (Agronomy) from Universitas Muhammadiyah Sumatera Utara, Indonesia in 1998. He continued study at Universitas Syiah Kuala, Banda Aceh, Indonesia in 2006 to get MM degree and get his doctorate degree in Management Science from Universitas Pendidikan Indonesia, Bandung, Indonesia in 2019.

He has over 12 years of professional experience in in banking and is now a lecturer in management study program at Faculty of Economics and Business, Universitas Islam Bandung, Indonesia.

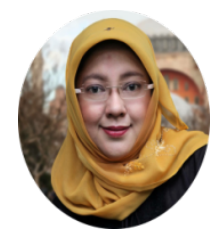

Ratih Hurriyati is a Professor in the Faculty of Economic Education and Business, Universitas Pendidikan Indonesia, Bandung, Indonesia. She is lecturer and researcher at management master program and doctorate program SPs Universitas Pendidikan Indonesia.

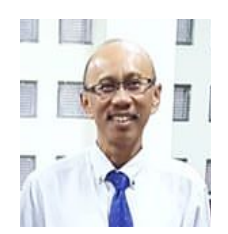

Disman is a Professor in the Faculty of Economic Education and Business, Universitas Pendidikan Indonesia, Bandung, Indonesia.

$\mathrm{He}$ is lecturer and researcher at management master program and doctorate program SPs Universitas Pendidikan Indonesia.

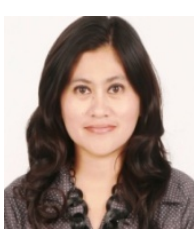

Vanessa Gaffar is a Associate Professor in the Faculty of Economic Education and Business, Universitas Pendidikan Indonesia, Bandung, Indonesia.

She is lecturer and researcher at management master program and doctorate program SPs Universitas Pendidikan Indonesia.

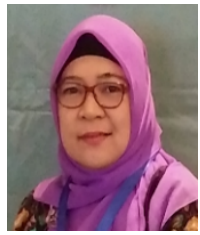

Dita Amanah earned her undergraduate degree (Management) from Universiti Kebangsaan Malaysia in 1996. She continued masters degree also at Universiti Kebangsaan Malaysia and completed in 1999 to get MBA. Get the doctorate degree in 2019 at Universitas Pendidikan Indonesia, Bandung, Indonesia.

She has over 19 years of professional experience is a lecturer majoring in marketing management at Universitas Negeri Medan, Indonesia. 